\title{
PENERAPAN MODEL PEMBELAJARAN MISSOURI MATHEMATICS PROJECT (MMP) DALAM MENINGKATKAN HASIL BELAJAR SISWA KELAS X.IPA.1 SMAN 3 MUARO JAMBI TAHUN PELAJARAN 2018/2019
}

\author{
NURHADI SABAR \\ SMA Negeri 3 Muaro Jambi, Provinsi Jambi \\ Email : noorhadi2602@gmail.com
}

\begin{abstract}
ABSTRAK
Penelitian ini bertujuan untuk meningkatkan hasil belajar matematika siswa kelas X.IPA.1 SMA Negeri 3 Muaro Jambi dengan menerapkan model pembelajaran Missouri Mathematic Project (MMP). Penelitian ini adalah Penelitian Tindakan Kelas (PTK). Subjek penelitian ini adalah siswa Kelas X.IPA.1 SMA Negeri 3 Muaro Jambi yang berjumlah 30 orang pada tahun pelajaran 2018/2019. Penelitian ini dilakukan dalam 2 (dua) siklus yaitu siklus I dan siklus II. Pengambilan data dilakukan dengan menggunakan tes hasil belajar dan observasi. Analisis data yang digunakan adalah analisis kuantitatif dan kualitatif. Hasil analisis kuantitatif menunjukan bahwa terjadi peningkatan skor rata-rata hasil belajar pada siklus I mencapai rata-rata 58,54 dan pada siklus II meningkat menjadi 86,04. Berdasarkan kategori ketuntasan hasil belajar yang digunakan, perolehan skor hasil belajar matematika siswa yang dikategorikan tuntas pada siklus I sebesar 24,00\% dan pada siklus II 97,00\%, sedangkan hasil analisis kualitatif berupa lembar observasi siswa dan guru, dengan hasil observasi aktivitas siswa mengalami peningkatan sebesar $8,35 \%$, sedangkan aktivitas guru berada pada kategori baik. Sehingga dapat disimpulkan bahwa terjadi peningkatan hasil belajar matematika siswa Kelas X.IPA.1 SMA Negeri 3 Muaro Jambi dengan penerapan model pembelajaran pembelajaran Missouri Mathematic Project (MMP).

Kata Kunci:Missouri Mathematic Project (MMP), hasil belajar
\end{abstract}

\section{PENDAHULUAN}

Pendidikan adalah sejatinya memiliki aktifitas vital dalam membangun sumber daya manusia yakni kegiatan belajar. Belajar merupakan salah satu faktor yang mempengaruhi dan berperan penting dalam pembentukan pribadi dan perilaku individu. Sebagian besar perkembangan individu berlangsung melalui kegiatan belajar (Hadi, 2019: 53-61). Salah satu usaha untuk meningkatkan pendidikan adalah dengan meningkatkan kualitas pendidikan matematika. Pendidikan matematika memiliki peranan yang penting dalam perkembangan pendidikan di Indonesia. Pendidikan matematika terangkum di dalamnya proses mengajar, proses belajar, dan proses berpikir kreatif. Saat mempelajari matematika, siswa secara langsung belajar untuk berpikir logis, sistematis, dan rasional dalam sebuah pemecahan masalah sehingga dicapai kemampuan yang berkembang sebagai sesuatu yang vital dalam pendidikan (Faradhila, 2013).

Matematika merupakan ilmu universal yang mendasari perkembangan teknologi modern, mempunyai peranan penting dalam berbagai disiplin dan memajukan daya pikir manusia. Matematika mempunyai ciri-ciri khusus sehingga pendidikan dan pengajaran matematika perlu ditangani secara khusus pula. Salah satu ciri khusus matematika adalah sifatnya yang menekankan pada proses deduktif yang memerlukan penalaran logis dan aksiomatik. Demikian pula matematika sebagai proses yang aktif, dinamik dan generatif melalui kegiatan matematika (doing math) (Purwanti, 2015). Perkembangan pesat dalam bidang teknologi informasi dan komunikasi dewasa ini dilandasi oleh perkembangan matematika. Untuk menguasai dan menciptakan teknologi dimasa depan diperlukan penguasaan matematika yang kuat sejak dini. Matematika adalah salah satu mata pelajaran yang memegang peranaan yang begitu penting dalam kehidupan manusia. Hampir setiap aktivitas keseharian manusia yang secara tidak langsung akan berhubungan dengan matematika. Dalam proses pembelajaran matematika, siswa kurang didorong untuk 


\section{STRATEGY : Jurnal Inovasi Strategi dan Model Pembelajaran Vol 1. No 1. Juli Tahun 2021 e-ISSN : 2798-5466 P-ISSN : 2798-5725}

mengembangan kemampuan berpikirnya. Salah satunya adalah melalui pengunaan yang tepat dalam proses pembelajaran. Hal ini sesuai dengan pernyataan Handoko (2013:189) yang menyatakan bahwa "matematika dapat difungsikan untuk mengembangkan kemampuan berpikir yang sistematis, logis, kreatif, disiplin, dan kerjasama yang efektif dalam kehidupan yang modern dan kompetitif".

Guru menempati posisi terdepan yang langsung berhadapan dengan peserta didik untuk mentransfer ilmu pengetahuan dan teknologi sekaligus mendidik dengan nilai-nilai positif melalui bimbingan dan keteladanan. Guru diharapkan dapat menciptakan situasi yang interaktif, dimana guru bisa berinteraksi dengan siswa, siswa dengan siswa, maupun siswa dengan media belajar. Siswa dituntut untuk mempunyai minat terhadap pelajaran matematika (Haryono, 2014: 43). Dengan demikian juga guru sebagai tenaga pengajar dituntut untuk lebih menguasai materi serta mampu memilih model pembelajaran yang tepat, agar tercipta interaksi edukatif yang baik menuju kearah peningkatan hasil belajar matematika siswa, sehingga siswa dapat termotivasi dalam belajar dan dapat meningkatkan siswa dalam berpikir kritis dan kreatif secara matematis.(Trianto, 2011: 75). Siswa yang berpikir kritis matematis akan cenderung memiliki sikap yang positif terhadap matematika, sehingga akan berusaha menalar dan mencari strategi penyelesaian masalah matematika (Husnidar, Ikhsan, \& Rizal, 2014).

Kurang keaktifan siswa dalam mengkomunikasikan gagasan dan menyelesaikan masalah menjadikan suatu masalah dalam pembelajaran matematika, sehingga peningkatan kualitas pembelajaran merupakan hal yang mendasar bagi peningkatan hasil belajar matematika. Selain itu, rendahnya hasil belajar matematika juga dipengaruhi oleh kurangnya kemampuan siswa menganalisis masalah-masalah matematika yang diberikan oleh guru.

Mengatasi permasalahan yang terjadi diperlukan suatu model pembelajaran yang mampu mengakomodasi beberapa aspek untuk mencapai tujuan pembelajaran. Berbagai model pembelajaran diterapkan dan masih memiliki beberapa kelemahan. Oleh karena itu, penelitian ini mempunyai tujuan menghadirkan model pembelajaran yang menutupi kelemahan model yang selama ini diterapkan yang berguna untuk meningkatkan pemahaman konsep siswa dalam pembelajaran matematika (Asfar, Asfar, Sartina, 2018: 23-38).

Salah satu model pembelajaran matematika yang memberikan peluang bagi siswa untuk mengembangkan kemampuan berpikir kreatif matematis dan pemecahan masalah siswa adalah model pembelajaran Missouri Mathematics Project (MMP). Menurut Agoestanto dan Savitri (2013:72) menyatakan bahwa "model pembelajaran Missouri Mathematics Project (MMP) menuntut keaktifan siswa dalam pembelajaran karena guru hanya sebagai fasilitator yang mendampingi dan hanya membantu siswa menemukan pengetahuannya". Senada dengan Agoestanto dan Savitri menurut Gitaniasari dalam Jannah (2013:66) model Missouri Mathematics Project (MMP) merupakan suatu program yang didesain untuk membantu guru dalam hal efektivitas penggunaan latihan-latihan agar siswa mencapai peningkatan yang luar biasa. Pendapat di atas dapat disimpulkan bahwa dengan diterapkannya model Missouri Mathematics Project (MMP) diharapkan dapat meningkatkan belajar siswa.

Model Missouri Mathematics Project (MMP) merupakan suatu program yang didesain untuk membantu guru dalam hal efektivitas penggunaan latihan-latihan agar siswa mencapai peningkatan yang luar biasa. Latihan-latihan yang dimaksud yaitu lembar tugas proyek, dimana pada saat kegiatan belajar mengajar guru memberikan tugas proyek kepada siswa agar siswa dapat mengerjakan soal-soal tersebut dengan tujuan untuk membantu siswa agar lebih mudah memahami materi yang dijelaskan oleh Guru. Dalam model pembelajaran MMP, siswa tidak hanya belajar di dalam Kelas saja karena siswa diberikan pekerjaan rumah sehingga siswa mempunyai waktu belajar yang lebih banyak. Tugas-tugas yang telah dikerjakan oleh siswa akan dibahas bersama-sama sehingga siswa akan mengetahui apakah jawaban yang didapatnya benar atau salah (Marliani, 2016).

Model pembelajaran Missouri Mathematics Project (MMP) banyak memiliki kelebihan diantaranya, siswa diberikan banyak latihan-latihan soal sehingga terampil dalam 
mengerjakan berbagai macam soal. Latihan-latihan soal tersebut diantaranya adalah lembar kerja siswa, latihan kelompok, dan tugas rumah/PR. Selain itu banyak materi bisa tersampaikan kepada siswa karena tidak memakan banyak waktu. Artinya, penggunaan waktu relatif lebih ketat.

Berdasarkan uraian latar belakang di atas, maka peneliti tertarik melakukan penelitian tentang penerapan model pembelajaran Missouri Mathematic Project (MMP) untuk meningkatkan hasil belajar matematika siswa Kelas X.IPA.1 SMA Negeri 3 Muaro Jambi.

\section{METODE PENELITIAN}

Penelitian ini adalah Penelitian Tindakan Kelas (Classroom Action Research), yang akan dilakukan dalam 2 (dua) siklus atau lebih untuk melihat peningkatan hasil belajar siswa yang akan dilaksanakan dalam beberapa tahap yaitu: Menyusun (plan), bertindak (act), mengamati (Observe), dan refleksi (reflection). Penelitian ini dilaksanakan di SMA Negeri 3 Muaro Jambi tahun pelajaran 2018/2019 dengan subjek penelitian ini adalah Kelas X.IPA.1.

Sebelum melaksanakan penelitian maka terlebih dahulu dilakukan perencanaan agar penelitian berjalan dengan lancar. Hal yang dilakukan adalah: (1) menelaah kurikulum untuk bidang studi matematika, (2) mempersiapkan perangkat pembelajaran berupa rencana pembelajaran, buku peserta didik, lembar kerja peserta didik, (3) mempersiapkan tes hasil belajar matematika. Pelaksanaan penelitian dilakukan dengan menerapkan model pembelajaran Missouri Mathematic Project (MMP) pada Kelas yang terpilih yaitu Kelas X.IPA.1. Instrumen yang digunakan untuk megumpulkan data yaitu tes hasil belajar matematika. Bentuk tes yang digunakan yaitu tes uraian.

Data yang telah terkumpul dari Kelas sampel selanjutnya dianalisis dengan menggunakan teknik statistik deskriptif. Analisis deskriptif ini digunakan untuk mendeskripsikan skor hasil belajar matematika Kelas X.IPA.1 SMA Negeri 3 Muaro Jambi yang diajar dengan menerapkan model pembelajaran Missouri Mathematic Project (MMP). Adapun indikator keberhasilan dalam penelitian ini adalah jika siswa yang tuntas atau melebihi nilai KKM sebanyak 85\% dari skor 100 ideal.

\section{HASIL DAN PEMBAHASAN}

Tabel 1. Gambaran peningkatan hasil belajar matematika siswa Kelas X.IPA.1 SMA Negeri 3 Muaro Jambi pada siklus I dan siklus II

\begin{tabular}{cccccccc}
\hline No. & Siklus & \multicolumn{6}{c}{ Nilai } \\
& & Subjek & Ideal & Tertinggi & Terendah & $\bar{x}$ & Me \\
\hline 1 & I & 30 & 100 & 92 & 40 & 59,44 & 55 \\
\hline 2 & II & 30 & 100 & 96 & 74 & 85,04 & 84 \\
\hline
\end{tabular}

Berdasarkan tabel di atas dapat dilihat bahwa rata-rata hasil belajar matematika siswa pokok bahasan mengenai sistem persamaan linear yang dilaksanakan dua siklus mengalami peningkatan.

Dalam penelitian ini diterapkan model pembelajaran Missouri Mathematic Project (MMP) yang terdiri dari dua siklus, penelitian ini mendapatkan hasil yang lebih baik lagi yakni dengan meningkatnya kualitas proses dan kemampuan penalaran matematika siswa Kelas X.IPA.1 SMA Negeri 3 Muaro Jambi. Berdasarkan analisis deskriptif hasil belajar matematika siswa Kelas X.IPA.1 SMA Negeri 3 Muaro Jambi tidak sesuai yang diharapkan pada tahap perencanaan dimana diperoleh rata-rata nilai hasil belajar matematika siswa pada siklus I adalah sebesar 59,44 dan dalam kategori penilaian SMA Negeri 3 Muaro Jambi hasil belajar matematika tersebut berada pada kategori rendah dengan persentase $16,66 \%$ tetapi kriteria ketuntasan minimal (KKM) siklus I belum mencapai secara klasikal 85\% dari jumlah siswa Kelas X.IPA.1 SMA Negeri 3 Muaro Jambi. Dari 30 siswa yang ikut tes pada siklus I 


\section{STRATEGY : Jurnal Inovasi Strategi dan Model Pembelajaran \\ Vol 1. No 1. Juli Tahun 2021 e-ISSN : 2798-5466 P-ISSN : 2798-5725}

terdapat 23 orang yang tergolong dalam kategori tidak tuntas yakni yang mencapai nilai 0-74, dan terdapat 7 orang tergolong tuntas yakni siswa yang mencapai nilai antara 75-100.

Perubahan sikap siswa dalam mengikuti proses belajar mengajar pada awal pertemuan selama siklus I masih sangat kurang dilihat dari beberapa siswa yang masih belum mengembangkan minat/rasa ingin tahunya, sehingga tidak termotivasi untuk belajar, masih kurangnya siswa menanggapi atau menjawab pertanyaan yang disampaikan oleh peneliti berdasarkan dengan materi yang telah dijelaskan, serta kurang aktifnya siswa untuk bertanya terkait dengan materi yang diberikan.

Berdasarkan analisis deskriptif hasil belajar matmatika siswa Kelas X.IPA.1 SMA Negeri 3 Muaro Jambi pada siklus II mengalami penigkatan dimana perolehan nilai rata-rata 85,04 dari hasil belajar matematika siswa pada siklus II dan dalam kategori penilaian SMA Negeri 3 Muaro Jambi. Hasil belajar tersebut berada pada kategori sedang dengan persentase $60 \%$.

Ketuntasan hasil belajar matematika pada pokok bahasan sistem persamaan linear telah mencapai $100 \%$ dari KKM yang telah ditetapkan di SMA Negeri 3 Muaro Jambi. Jadi hasil belajar matematika siswa SMA Negeri 3 Muaro Jambi Kelas X.IPA.1 setelah menerapkan model pembelajaran Missouri Mathematic Project (MMP) pada setiap pembelajaran terjadi peningkatan. Dari 30 siswa yang ikut tes pada siklus II 29 orang yang memenuhi standar dan tergolong tuntas yakni siswa yang mencapai nilai Antara 75-100. Setelah itu. Peneliti semakin banyak memotivasi siswa dengan cara mengembangkan minat/rasa ingin tahu siswa dan mengikuti keinginan siswa dalam hal menginformasikan materi, memberikan jawaban yang jelas kepada siswa yang memberikan pertanyaan sehingga pada siklus II aktivitas siswa dan peneliti meningkat dari siklus I.

Perubahan rata-rata nilai hasil belajar dari siklus I ke siklus II serta perubahan sikap siswa dan perubahan aktivitas guru terjadi selama proses belajar mengajar, dapat disimpulkan bahwa dengan menerapkan strategi interaktif dan model pembelajaran Missouri Mathematic Project (MMP) setiap pembelajaran, siswa lebih aktif berinteraksi dan juga lebih aktif untuk menyelesaikan soal-soal latihan yang diberikan. Dimana model pembelajaran Missouri Mathematic Project (MMP) adalah suatu cara atau teknik pembelajaran yang digunakan guru pada saat menyajikan bahan pelajaran, dimana guru menjadi pemeran utama dalam menciptakan situasi interaktif yang edukatif, yakni interaksi antara guru dengan siswa, siswa dengan siswa dan dengan sumber belajar sehingga proses pembelajaran lebih hidup dan siswa lebih bersemangat. Model pembelajaran Missouri Mathematic Project (MMP) juga melatih siswa terhadap bahan pelajaran yang sudah diberikan.

Penelitian ini didukung pula oleh penelitian sebelumnya yang sejenis Ana Fauziah dan Sukasno (2015) dalam penelitiannya yang berjudul "Pengaruh Model Missouri Mathematics Project (MMP) Terhadap Kemampuan Pemahaman dan Pemecahan Masalah Matematika Siswa SMAN I Lubuklinggau”. Dengan hasil penelitiannya yang menyatakan Model MMP berpengaruh secara signifikan terhadap kemampuan pemecahan masalah matematika siswa.

Dengan demikian, setelah diterapkan model pembelajaran Missouri Mathematic Project (MMP) hasil belajar matematika pada siswa Kelas X.IPA.1 SMA Negeri 3 Muaro Jambi meningkat serta proses belajar terjadi perubahan sehingga aktivitas siswa dapat meningkat.

\section{KESIMPULAN}

Berdasarkan hasil yang diperoleh dalam penelitian ini, maka dapat disimpulkan bahwa dengan menerapkan model pembelajaran Missouri Mathematic Project (MMP) maka hasil belajar matematika siswa Kelas X.IPA.1 SMA Negeri 3 Muaro Jambi tahun pelajaran 2018/2019 meningkat. Hal ini dapat dilihat dari skor rata-rata hasil belajar matematika siswa pada siklus I yaitu 59,43 dengan standar deviasi 15,215 dan pada siklus II yaitu 85,03 dengan standar deviasi 5,804 dari ketuntasan klasikal terpenuhi yaitu minimal 85\%. 


\section{DAFTAR PUSTAKA}

Agoestanto, A., \& Safitri, S. N. (2013, October). Keefektifan pembelajaran matematika mengacu pada missouri mathematics project terhadap kemampuan pemecahan masalah. In Prosiding Seminar Nasional Matematika VII UNNES (Vol. 26, pp. 71-77).

Arikunto, Suharsini. (2011). Penelitian Tindakan Untuk Guru, Kepala Sekolah dan Pengawas. Yogyakarta: Aditya Media.

Asfar, A. I. T., Asfar, A. I. A. A. A., \& Sartina, S. (2018). Modifikasi model pembelajaran missouri mathematics project (MMP) dengan model pembelajaran explicit intruction (EI) dalam meningkatkan pemahaman konsep matematika siswa. Aksara Public, 2(4), 23-38.

Faradhila, N. (2013). Eksperimentasi Model Pembelajaran Missouri Mathematics Project (Mmp) Pada Materi Pokok Luas Permukaan Serta Volume Prisma Dan Limas Ditinjau Dari Kemampuan Spasial Siswa Kelas Viii Semester Genap Smp Negeri 2 Kartasura Tahun Ajaran 2011/2012.

Hadi, A. (2019). Peningkatan hasil belajar matematika melalui strategi interaktif dengan menggunakan metode pembelajaran drill pada siswa Kelas XI MIPA 6 SMA Negeri 16 Makassar. EQUALS: Jurnal Ilmiah Pendidikan Matematika, 2(2), 53-61.

Handoko, H. (2013, October). Pembentukan Kemampuan Berpikir Kreatif Pada Pembelajaran Matematika Model SAVI Berbasis Discovery Strategy di Laboratorium Teezania. In Prosiding Seminar Nasional Matematika VII UNNES (Vol. 26, pp. 287-291).

Haryono, Didi. (2014). Filsafat Matematika Suatu Tinjauan Epistemologi dan Filosofis. Bandung: Alfabeta.

Husnidar, H., Ikhsan, M., \& Rizal, S. (2014). Penerapan Model Pembelajaran Berbasis Masalah untuk Meningkatkan Kemampuan Berpikir Kritis dan Disposisi Matematis Siswa. Jurnal Didaktik Matematika, 1(1).

Jannah, dkk. (2013). Penerapan Model Missouri Mathematic Project (MMP) untuk Meningkatkan Pemahaman dan Sikap Positif Siswa Pada Materi Fungsi. Jurnal Pendidikan Matematika Solusi. 1(1): 61-66.

Marliani, N. (2016). Pengaruh model pembelajaran missouri mathematics project terhadap kemampuan berpikir kreatif matematis siswa. JPPM (Jurnal Penelitian dan Pembelajaran Matematika), 9(1).

Purwanti, S. (2015). Meningkatkan Kemampuan Komunikasi Dan Berpikir Kritis Matematis Siswa Sekolah Dasar Dengan Model Missouri Mathematics Project (MMP). TERAMPIL: Jurnal Pendidikan Dan Pembelajaran Dasar, 2(2), 253-266.

Trianto. (2011). Model-model Pembelajaran Inovatif Berorientasi Konstruktivistik. Jakarta: Prestasi Pustaka Publisher. 